Article

\title{
Selenium Content in Seafood in Japan
}

\section{Yumiko Yamashita *, Michiaki Yamashita and Haruka Iida}

National Research Institute of Fisheries Science, Kanazawa, Yokohama, Kanagawa, 236-8648, Japan; E-Mails: mic@affrc.go.jp (M.Y.); harukaiida@affrc.go.jp (H.I.)

* Author to whom correspondence should be addressed; E-Mail: ymk0125@affrc.go.jp;

Tel.: +81-45-788-7665; Fax: +81-45-788-5001.

Received: 5 January 2013; in revised form: 24 January 2013 / Accepted: 25 January 2013 /

Published: 31 January 2013

\begin{abstract}
Selenium is an essential micronutrient for humans, and seafood is one of the major selenium sources, as well as red meat, grains, eggs, chicken, liver and garlic. A substantial proportion of the total amount of selenium is present as selenium containing imidazole compound, selenoneine, in the muscles of ocean fish. In order to characterize the selenium content in seafood, the total selenium levels were measured in the edible portions of commercially important fish and shellfish species. Among the tested edible portions, alfonsino muscle had the highest selenium levels (concentration of $1.27 \mathrm{mg} / \mathrm{kg}$ tissue). High levels of selenium $(1.20-1.07 \mathrm{mg} / \mathrm{kg})$ were also found in the salted ovary products of mullet and Pacific herring. In other fish muscles, the selenium levels ranged between 0.12 and $0.77 \mathrm{mg} / \mathrm{kg}$ tissue. The selenium levels were closely correlated with the mercury levels in the white and red muscles in alfonsino. The selenium content in spleen, blood, hepatopancreas, heart, red muscle, white muscle, brain, ovary and testis ranged between 1.10 and $24.8 \mathrm{mg} / \mathrm{kg}$ tissue in alfonsino.
\end{abstract}

Keywords: selenium; mercury; food safety; muscle; fish; seafood

\section{Introduction}

Selenium is an essential nutrient for humans [1-3]. Selenium is a constituent of antioxidant enzymes and proteins, such as glutathione peroxidases, thioredoxin reductases and selenoprotein $\mathrm{P}$, which contain one or more selenocysteine residues [1-3]. Selenium bioavailability may depend on the food source and chemical forms of selenium [4]. The major compounds in plant foods are selenite, 
selenomethionine and $\gamma$-glutamyl methylselenocysteine [4]. Although there are limited data on the chemical forms of organic selenium in foods of animal origin, the major chemical form of selenium is considered to be selenocysteine and selenomethionine that are incorporated in muscle proteins [4].

The dietary intake of selenium by fish consumption may be important for the enhancement of selenium redox function. Fish are estimated to be the major selenium source in Japan, contributing to approximately $35 \%$ of the total selenium consumed [1]. Therefore, the selenium content and its chemical forms in the edible portions of fish and shellfish should be characterized.

Recent studies showed that the fish muscles of tuna and other predatory fish contain high levels of the selenium-containing imidazole compound, 2-selenyl- $N_{\alpha}, N_{\alpha}, N_{\alpha}$-trimethyl-L-histidine (selenoneine) [5-7]. This compound was identified as the major organic selenium in the blood and muscle tissue of tuna [5-7]. Selenoneine contains an imidazole ring with a unique selenoketone group and has radical scavenging activity [5]. Therefore, the dietary intake of selenoneine through fish consumption is thought to be important for enhancing antioxidant effects in tissues and cells.

Selenium intake reduces methylmercury $(\mathrm{MeHg})$ toxicity [8-11]. The risk of fish consumption is thought to be provided by measuring not only the $\mathrm{MeHg}$ exposure, but also the levels of selenium and other components that benefit health and reduce $\mathrm{MeHg}$ toxicity [10].

This study compared the selenoneine and total selenium content of the fish muscle in commercially important fish species in Japan.

\section{Experimental Section}

\subsection{Materials}

The fish samples were obtained at a local market in Tokyo and stored frozen at $-40{ }^{\circ} \mathrm{C}$ until use. Fillet samples of three individuals were mixed into a single composite sample, and the mean value of three composite samples was determined for the total selenium analysis, except for alfonsino. For the selenium and mercury analysis of alfonsino, 24 fish (average body weight: $1.953 \pm 0.584 \mathrm{~kg}$ ) were used, and various tissues, such as spleen, blood, hepatopancreas, heart, red muscle, white muscle, brain, ovary and testis, were collected from each individual.

\subsection{Selenium Concentration Measurement}

The fish sample $(0.1-0.2 \mathrm{~g})$ was digested at $200-220^{\circ} \mathrm{C}$ in $1 \mathrm{~mL}$ of a $1: 2$ mixture of nitric acid and perchloric acid. The selenium concentration was determined by hydride generation atomic absorption spectroscopy. For the selenium analysis of the alfonsino tissues, the selenium concentration was determined by a fluorometric assay using 2,3-diamino-naphthalene [8,12].

\subsection{Mercury Concentration Determination}

The total mercury levels were determined by flameless atomic absorption spectrometry at $253.7 \mathrm{~nm}$ using an HG-310 mercury analyzer (Hiranuma, Tokyo, Japan) according to the manufacturer's instructions. The sample material $(0.1-0.5 \mathrm{~g})$ was first digested in $2 \mathrm{~mL}$ of a $1: 2: 1$ mixture of nitric acid/perchloric acid/sulfuric acid and diluted in water to $25-125 \mathrm{~mL}$. 


\section{Results}

The levels of total selenium were determined in the edible portions of various fish and shellfish in Japan (Tables 1 and 2). Alfonsino muscle contained the highest level of selenium $(1.40 \mathrm{mg} / \mathrm{kg})$ among the fish muscles examined in this study. High levels of selenium (1.20-1.07 mg/kg) were also found in the salted ovary products of mullet and Pacific herring. In other fish muscles, the selenium levels ranged between 0.12 and $0.77 \mathrm{mg} / \mathrm{kg}$ tissue.

Table 1. Selenium content in the edible portions of fish and shellfish.

\begin{tabular}{|c|c|c|c|c|}
\hline name & species & $\begin{array}{c}\text { Japanese } \\
\text { name } \\
\end{array}$ & portion & $\begin{array}{r}\text { selenium } \\
(\mathrm{mg} / \mathrm{kg})\end{array}$ \\
\hline alfonsino & Beryx splendens & kinmedai & fillet & 1.27 \\
\hline Japanese bluefish & Scombrops boops & mutsu & fillet with skin & 0.77 \\
\hline \multirow[t]{2}{*}{ Pacific bluefin tuna } & Thunnus orientalis & kuromaguro & fillet (low-fat) & 0.75 \\
\hline & & & fillet (high-fat) & 0.72 \\
\hline albacore & Thunnus alalunga & bin-naga & fillet & 0.75 \\
\hline skipjack & Euthynnus pelamis & katsuo & fillet with skin & 0.62 \\
\hline \multirow[t]{2}{*}{ Japanese flounder } & Paralichthys olivaceus & hirame & fillet with skin ${ }^{c}$ & 0.56 \\
\hline & & & fillet with skin ${ }^{\mathrm{w}}$ & 0.42 \\
\hline hoki & Macruronus novaezelandiae & hoki & fillet with skin & 0.56 \\
\hline loach & Misgurnus anguillicaudatus & dojou & whole & 0.50 \\
\hline southern black cod & Dissostichus eleginoides & mero & fillet & 0.49 \\
\hline Pacific ocean perch & Sebastes alutus & alaska-menuke & fillet & 0.49 \\
\hline golden-thread & Nemipterus virgatus & itoyoridai & surimi & 0.48 \\
\hline conger pike & Muraenesox cinereus & hamo & fillet with skin & 0.47 \\
\hline yellowtail & Seriola quinqueradiata & buri & fillet with skin ${ }^{\mathrm{w}}$ & 0.46 \\
\hline Pacific mackerel & Scomber japonicus & masaba & fillet with skin & 0.40 \\
\hline Pacific herring & Clupea pallasii & nishin & fillet with skin & 0.40 \\
\hline sailfin sandfish & Arctoscopus japonicus & hatahata & fillet with skin & 0.40 \\
\hline gurnard & Chelidonichthys spinosus & houbou & fillet with skin & 0.39 \\
\hline Asian yellowtail & Seriola lalandi & hiramasa & fillet with skin & 0.38 \\
\hline Japanese scallops & Pecten albicans & itayagai & without shell & 0.37 \\
\hline masu salmon & Oncorhynchus masou & sakuramasu & fillet with skin & 0.35 \\
\hline three-line grunt & Parapristipoma trilineatum & isaki & fillet with skin & 0.35 \\
\hline striped jack & Caranx delicatissimus & shima-aji & fillet with skin ${ }^{c}$ & 0.32 \\
\hline Japanese seabass & Lateolabrax japonicus & suzuki & fillet with skin & 0.32 \\
\hline lamprey & Lethenteron japonicum & yatsumeunagi & fillet with skin & 0.32 \\
\hline Pacific halibut & Hippoglossus stenolepis & ohyou & fillet with skin & 0.31 \\
\hline Japanese surf smelt & Hypomesus pretiosus & chika & fillet with skin & 0.31 \\
\hline silver pomfret & Pampus punctatissimus & managatsuo & fillet with skin & 0.31 \\
\hline Japanese common squid & Todarodes pacificus & surumeika & without viscera & 0.30 \\
\hline \multirow[t]{2}{*}{ rainbow trout } & Oncorhynchus mykiss & nijimasu & fillet with skin ${ }^{\mathrm{cs}}$ & 0.29 \\
\hline & & & fillet with skin ${ }^{\text {cf }}$ & 0.26 \\
\hline Japanese parrot fish & Oplegnathus fasciatus & ishidai & fillet with skin & 0.29 \\
\hline coho salmon & Oncorhynchus kitsch & ginzake & fillet with skin ${ }^{c}$ & 0.28 \\
\hline
\end{tabular}


Table 1. Cont.

\begin{tabular}{|c|c|c|c|c|}
\hline Chinook salmon & Oncorhynchus tshawytscha & masunosuke & fillet with skin & 0.28 \\
\hline Japanese whiting & Sillago japonica & shirogisu & fillet with skin & 0.28 \\
\hline flying fish & Cypselurus agoo agoo & tobiuo & fillet with skin & 0.28 \\
\hline sockeye salmon & Oncorhynchus nerka & benizake & fillet with skin & 0.23 \\
\hline Pacific cod & Gadus macrocephalus & madara & fillet with skin & 0.23 \\
\hline walleye pollock & Theragra chalcogramma & suketoudara & fillet with skin & 0.22 \\
\hline Atlantic mackerel & Scomber scombrus & taiseiyousaba & fillet with skin & 0.23 \\
\hline mullet & Mugil cephalus & mabora & fillet with skin & 0.21 \\
\hline char & Salvelinus pluvius & iwana & fillet with skin ${ }^{\mathrm{c}}$ & 0.21 \\
\hline short-neck clam & Ruditapes philippinarum & asari & without shell & 0.21 \\
\hline amago salmon & Oncorhynchus masou ishikawae & amago & fillet with skin ${ }^{\mathrm{c}}$ & 0.20 \\
\hline hairtail & Trichiurus lepturus & tachiuo & fillet with skin & 0.19 \\
\hline ocellate puffer & Takifugu rubripes & torafugu & fillet $^{c}$ & 0.17 \\
\hline walleye pollock & Theragra chalcogramma & suketoudara & surimi & 0.16 \\
\hline crucian carp & Carassius auratus & funa & fillet with skin & 0.16 \\
\hline Coho salmon & Oncorhynchus kitsch & ginzake & fillet with skin ${ }^{\mathrm{w}}$ & 0.15 \\
\hline Atlantic salmon & Salmo salar & taiseiyousake & fillet with skin & 0.15 \\
\hline purple puffer & Takifugu porphyreus & mafugu & fillet & 0.14 \\
\hline Japanese eel & Anguilla japonica & unagi & fillet with skin ${ }^{\mathrm{c}}$ & 0.12 \\
\hline
\end{tabular}

Table 2. Selenium content in the edible portions of fish.

\begin{tabular}{ccccc}
\hline name & species & Japanese name & portion & $\begin{array}{c}\text { selenium } \\
(\mathbf{m g} / \mathbf{k g})\end{array}$ \\
\hline Pacific cod & Gadus macrocephalus & madara & testis & 0.14 \\
Pacific herring & Clupea pallasii & nishin & ovary & 1.07 \\
mullet & Mugil cephalus & mabora & salted ovary & 1.20 \\
\hline
\end{tabular}

Because alfonsino muscles were previously shown to contain high levels of selenium and methylmercury [7,11], we compared the selenium and mercury content in the muscles and other tissues in alfonsino (Table 3). The selenium levels were closely correlated with the mercury levels in the white and red muscles in alfonsino (Figure 1a). The correlation coefficients between the selenium and mercury content in the white muscle were calculated to be $0.570(p=0.004)$, respectively. All tissues, including spleen, blood, hepatopancreas, heart, red muscle, white muscle, brain, ovary and testis, that were examined in this study contained high levels of selenium, with all being greater than $1 \mathrm{mg} / \mathrm{kg}$, and the highest selenium concentration was determined to be $24.8 \mathrm{mg} / \mathrm{kg}$ in the spleen. Se-to-Hg molar ratio in the white muscle of alfonsino was calculated in Fig. 1B. The Se-to-Hg molar ratio ranged from 0.83 to 6.4 , and was correlated with the body weight $(r=-0.504, p=0.020)$. 
Table 3. Distribution of selenium and mercury in the various tissues of alfonsino.

\begin{tabular}{cccc}
\hline tissue & $\boldsymbol{n}$ & $\mathbf{S e}(\mathbf{m g} / \mathbf{k g})$ & $\mathbf{H g} \mathbf{( m g / k g )}$ \\
\hline spleen & 6 & $24.8 \pm 7.18$ & $2.35 \pm 0.06$ \\
blood & 9 & $17.8 \pm 9.32$ & $0.61 \pm 0.26$ \\
hepatopancreas & 6 & $8.09 \pm 2.76$ & $3.92 \pm 1.51$ \\
heart & 6 & $4.38 \pm 1.04$ & $1.24 \pm 0.34$ \\
red muscle & 6 & $2.71 \pm 1.04$ & $1.08 \pm 0.20$ \\
white muscle & 24 & $1.27 \pm 0.77$ & $1.19 \pm 0.43$ \\
brain & 6 & $1.73 \pm 0.22$ & $1.62 \pm 0.35$ \\
ovary & 6 & $2.43 \pm 0.58$ & $0.40 \pm 0.12$ \\
testis & 6 & $1.10 \pm 0.18$ & $0.23 \pm 0.12$ \\
\hline
\end{tabular}

Figure 1. Relationship between the selenium and mercury content in the white and red muscles of alfonsino (Beryx splendens). (a) Relationship between the selenium and mercury contents; (b) Relationship between the body weight and Se/Hg molar ratio.

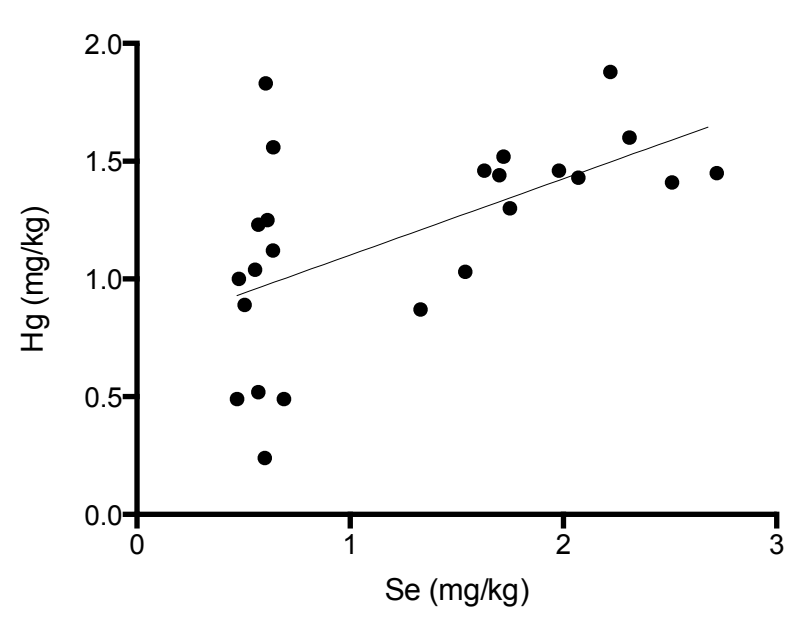

(a)

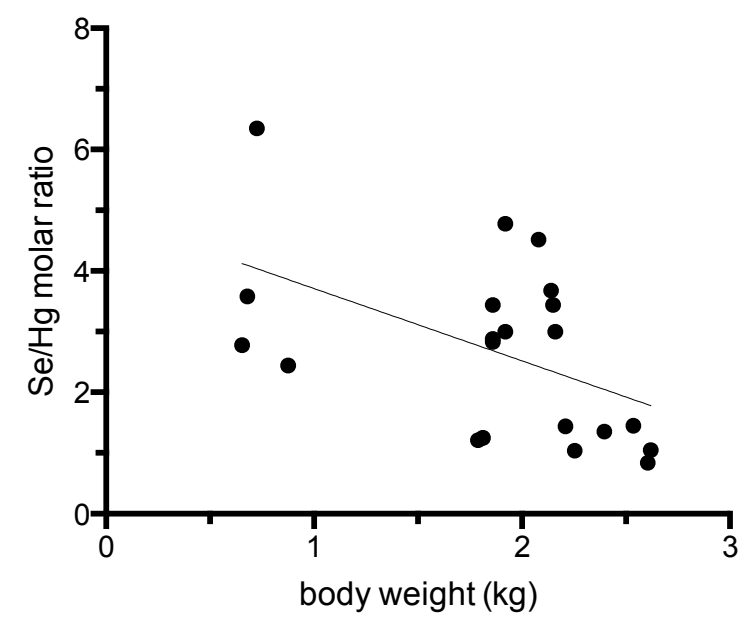

(b)

\section{Discussion}

The selenium levels were determined in tissues of various species of commercially important fish and shellfish in Japan. The highest level of selenium $(1.27 \mathrm{mg} / \mathrm{kg}$ tissue) was found in the muscle of alfonsino. Other predatory fish species, such as Japanese bluefish $(0.77 \mathrm{mg} / \mathrm{kg}$ tissue), Pacific bluefin tuna $(0.72-0.75 \mathrm{mg} / \mathrm{kg}$ tissue), albacore $(0.75 \mathrm{mg} / \mathrm{kg}$ tissue), skipjack (0.62 $\mathrm{mg} / \mathrm{kg}$ tissue), Japanese flounder $(0.42-0.56 \mathrm{mg} / \mathrm{kg}$ tissue) and hoki $(0.56 \mathrm{mg} / \mathrm{kg}$ tissue), also contained more than $0.5 \mathrm{mg} / \mathrm{kg}$ selenium in the muscle. Our previous paper reported that a large proportion of the organic selenium was present as selenoneine in the muscles of these predatory fish species [5-7]. However, several fish species, including Japanese conger, Japanese anchovy, chum salmon, Pacific saury, white croaker and marbled sole, contained selenoneine below the level of detection $(<0.05 \mathrm{nmol} / \mathrm{g}$ tissue $)$ [7]. Selenoproteins, including glutathione peroxidases (GPx) and selenoprotein $\mathrm{W}$, that contain selenium in the selenocysteine form might be present in fish muscles [13-17]. The most important source of selenium in the diets for Japanese is known to be fish [1]. 
Thioredoxin reductase 1 and 2 are known to reduce a variety of small molecules to restore them to forms which can function as antioxidants [18,19]. In addition, selenoneine may be an important component of the redox cycle in animal cells [5-7]. GPx and other selenoproteins, the expression of which is induced by selenium intake, are thought to enhance antioxidant activity in animal tissues and cells [13-17]. Selenoneine itself may play a key role as a strong free radical scavenger in a variety of physiological and nutritional processes [5-7].

Dietary selenium is postulated to protect against mercury toxicity and to reduce mercury accumulation [8-11]. Recently, we elucidated that selenoneine is an essential molecule in the $\mathrm{MeHg}$ detoxification pathway. Selenoneine was found to accelerate the excretion and demethylation of $\mathrm{MeHg}$ by secretory extracellular lysosomal vesicle formation via specific organic cation/carnitine transporter OCTN1 [20]. The dietary intake of selenium by fish consumption might reduce $\mathrm{MeHg}$ bioaccumulation and toxicity. The present study indicated that alfonsino white muscle contained the highest levels of selenium and mercury in seafood. The Se-to-Hg molar ratio ranges from 0.83 to 6.4, and decreased in older and larger fish. These findings suggest that mercury may be metabolized in closely related molecular mechanisms as selenium, and both mercury and selenium may be bioaccumulated in marine ecosystems. Our previous paper reported that the Se-to-Hg molar ratio ranges from 1 to 217 in the muscle of various fishes. The animal trials of feeding with both $\mathrm{MeHg}$ and sodium selenite showed that the toxicity of $\mathrm{MeHg}$ was reduced by selenium intake for a $\mathrm{Se}-\mathrm{to}-\mathrm{Hg}$ molar ratio above 0.2 [19]. Therefore, from the data on total selenium and mercury content, the alfonsino white muscle is thought to represent normal physiological states from the viewpoint of $\mathrm{MeHg}$ bioaccumulation and metabolism.

In conclusion, the selenium levels were determined in the edible portion of commercially important fish and shellfish in Japan, ranging between 0.12 and $1.27 \mathrm{mg} / \mathrm{kg}$ tissue. In alfonsino, the selenium levels were closely correlated with the mercury levels in the white and red muscles.

\section{Acknowledgments}

We thank S. Toda, T. Suzuki and T. Hara for selenium analysis. This work was supported in part by grants from the Japan Society for the Promotion of Science, the Fisheries Research Agency and the Ministry of Agriculture, Forestry and Fisheries of Japan.

\section{Conflict of Interest}

The authors declare no conflict of interest.

\section{References}

1. Combs, G.F.; Combs, S.B. The Role of Selenium in Nutrition; Academic Press: Orlando, FL, USA, 1986; pp. 1-532.

2. Himeno, S.; Imura, N. New aspects of physiological and pharmacological roles of selenium. J. Health Sci. 2000, 46, 1-6.

3. Rayman, M.P. The importance of selenium to human health. Lancet 2000, 356, 233-241. 
4. Fairweather-Tait, S.J.; Collings, R.; Hurst, R. Selenium bioavailability: Current knowledge and future research requirements. Am. J. Clin. Nutr. 2010, 91, S1484-S1491.

5. Yamashita, Y.; Yamashita, M. Identification of a novel selenium-containing compound, selenoneine, as the predominant chemical form of organic selenium in the blood of bluefin tuna. J. Biol. Chem. 2010, 285, 18134-18138.

6. Yamashita, Y.; Yabu, T.; Yamashita, M. Discovery of the strong antioxidant selenoneine in tuna and selenium redox metabolism. World J. Biol. Chem. 2010, 1, 144-150.

7. Yamashita, Y.; Amlund, H.; Suzuki, T.; Hara, T.; Hossain, A.M.; Yabu, T.; Touhata, K.; Yamashita, M. Selenoneine, total selenium, and total mercury content in the muscle of fishes. Fish. Sci. 2010, 77, 679-686.

8. Ganther, H.; Goudie, C.; Sunde, M.; Kopeckey, M.; Wagner, S.; Hoekstra, W. Selenium: Relation to decreased toxicity of methylmercury added to diets containing tuna. Science 1972, 175, 1122-1124.

9. Ralston, N.V.C.; Ralston, C.R.; Blackwell, J.L.; Raymond, L.J. Dietary and tissue selenium in relation to methylmercury toxicity. Neurotoxicology 2008, 29, 802-811.

10. Ralston, N.V.C.; Blackwell, J.L.; Raymond, L.J. Importance of molar ratios in selenium - dependent protection against methylmercury toxicity. Biol. Trace Elem. Res. 2007, 119, 255-268.

11. Yamashita, Y.; Omura, Y.; Okazaki, E. Total mercury and methylmercury levels in commercially important fishes in Japan. Fish. Sci. 2005, 71, 1029-1035.

12. Watkinson, J.H. Fluorometric determination of selenium in biological material with 2,3-diaminonapththalene. Anal. Chem. 1966, 38, 92-97.

13. Kryukox, G.V.; Gladyshev, V.N. Selenium metabolism in zebrafish: Multiplicity of selenoprotein genes and expression of a protein containing 17 selenocysteine residues. Genes Cells 2000, 5, 1049-1060.

14. Nagai, T.; Inada, J.; Hmada, M.; Kai, N.; Tanoue, Y.; Kaminishi, Y.; Nakagawa, H.; Fujiki, K.; Nakao, M. Distribution of glutathione peroxidase activity in fish. Fish. Sci. 1999, 65, 665-666.

15. Thompson, J.L.; See, V.H.L.; Thomas, P.M.; Schuller, K.A. Cloning and characterization of two glutathione peroxidase cDNAs from southern bluefin tuna (Thunnus maccoyii). Comp. Biochem. Physiol. 2010, 156, 287-297.

16. Yamashita, Y.; Yabu, T.; Touhata, K.; Yamashita, M. Purification and characterization of glutathione peroxidase 1 in the red muscle of bluefin tuna. Fish. Sci. 2012, 79, 407-411.

17. Vendeland, S.C.; Beilstein, M.A.; Chen, C.L.; Jensen, O.N.; Barofsky, E.; Whanger, P.D. Purification and properties of selenoprotein W from rat muscle. J. Biol. Chem. 1993, 268, 17103-17107.

18. Arnér, E.S. Focus on mammalian thioredoxin reductases-Important selenoproteins with versatile functions. Biochim. Biophys. Acta 2009, 1790, 495-526.

19. Ralston, N.V.; Raymond, L.J. Dietary selenium's protective effects against methylmercury toxicity. Toxicology 2010, 278, 112-123. 
20. Yamashita, M.; Yamashita, Y.; Suzuki, T.; Kani, K.; Mizusawa, N.; Imamura, S.; Takemoto, T.; Hara, T.; Hossain, M.A.; Yabu, T.; Touhata, K. National Research Institute of Fisheries Science, Yokohama, Japan. Selenoneine, a novel selenium-containing compound, mediates detoxification mechanisms against methylmercury accumulation and toxicity in zebrafish embryo. Mar. Biotechnol. 2013, submitted.

(C) 2013 by the authors; licensee MDPI, Basel, Switzerland. This article is an open access article distributed under the terms and conditions of the Creative Commons Attribution license (http://creativecommons.org/licenses/by/3.0/). 